\title{
Intractable Traits in Eastern U.S. Blackberries
}

\author{
John R. Clark \\ Department of Horticulture, University of Arkansas, Fayetteville, AR 72701
}

\begin{abstract}
Additional index words. Rubus, small fruit breeding, plant architecture, fruit quality
Abstract. Eastern U.S. blackberries are heterogeneous tetraploids. Some traits have been quite difficult to improve, and the example of erect-caned, thornless cultivar development is a good example. Thornlessness was associated with semi-erect canes, poor seed germination, and other undesirable traits, thus extending the amount of time to achieve an erect-caned, thornless cultivar. The first release of this type was 'Navaho' in 1989. Primocane fruiting is a trait that would not likely be considered intractable, but did not gain substantial attention until the late 1980s. Subsequent work in primocane fruiting has shown substantial progress in a relatively short time of breeding emphasis for this trait. Fruit size gains have been substantial, and even though this trait might be considered intractable, progress has been significant in the last $\mathbf{4 0}$ years. Excellent postharvest handling and flavor are additional traits which one might consider intractable. Substantial progress has been made in improving fruit quality for shipping, providing for an expansion in fruit shipped to distant markets. These and other improvements are expanding opportunities for blackberry growers worldwide.
\end{abstract}

Eastern U.S. blackberries are thought to be a genetically heterogeneous group of plants, largely derived from native germplasm. There is no current species epithet for this type of blackberry, and they are currently referred to as Rubus subgenus Rubus L., or Rubus subgenus Rubus Watson, or simply Rubus spp. (Ballington and Moore, 1995). The cultivated forms are tetraploids, $2 n=48$. Eastern U.S. blackberries differ from the commercially important trailing blackberries primarily grown in the western U.S. The western cultivars an equally diverse species background and have a ploidy range from $6 x(2 n=42)$ to $9 x(2 n=63)$.

Blackberries are perennials with biennial canes; the first-year canes are known as primocanes and these usually grow only vegetatively, and in the second year these canes flower, fruit, and senesce. Eastern U.S. blackberries are usually classed by cane architecture, either semi-erect- or erect-caned. Examples of the former type include the thornless 'Thornfree', 'Hull Thornless', 'Triple Crown', and 'Chester Thornless' (Daubeny, 1997; Moore, 1997). Erect-caned cultivars include the thorny 'Cherokee', 'Shawnee', and 'Chickasaw', along with the thornless 'Navaho', 'Arapaho', and 'Apache' (Finn and Clark, 2000). The discussion of intractable traits will focus on the story of breeding erect-caned, thornless blackberries, with some comments on breeding for primocane fruiting, flavor, and finally, fruit size and firmness.

\section{Breeding Erect-caned Thornless Blackberries}

James N. Moore established the University of Arkansas blackberry breeding program in 1964. At that time there were few adapted cultivars for Arkansas and the surrounding region. One of his breeding goals was to develop erect-caned thornless blackberries. In the mid-1960s, only semi-erect, thornless blackberries were available ('Thornfree' and 'Smoothstem', released in 1966) (Moore, 1997), and these cultivars, plus breeding selections from the U.S. Dept. of Agriculture breeding program based at Carbondale, Ill., were available as sources of thornless genes. Two thorny parents he chose were the mostly erect 'Brazos' from Texas, and the erect 'Darrow' from New York (Moore, 1997). However, neither of these cultivars were well adapted to Arkansas. His interest in having erect canes was to allow a production system that would not require trellis support, and potentially be machine harvestable.

Unfortunately, combining erect canes and thornless plants turned out to be "intractable" The major problems in combining these two traits included the quantitative nature of cane inheritance, coupled with associated negative traits that were inherited with thornlessness. These negative traits, in comparison to most of the thorny germplasm, included late-ripening, less cold hardy (in Arkansas), very tart flavor, variable drupelet fertility, small fruit size, poor seed germination, and poor adventitious shoot sprouting from roots. Erect $\times$ semi-erect crosses yielded small incremental increases in erectness, slowing the attainment of fully erectcaned plants. This challenge was made more difficult by the limited number of thornless progeny attained in segregating populations. The thornless trait, derived originally from the English cultivar Merton Thornless, is recessive (Jennings, 1988). Thus, populations of thornless $\times$ thorny progeny yielded only thorny offspring, and second-generation offspring of these parents (one-half thornless crosses, or $F_{1} s$ ) provided only one thornless plant in 36; crosses of $\mathrm{F}_{1} \mathrm{~s}$ by thornless yielded one in four thornless progeny. Seed germination of thornless crosses was much lower than that of thorny crosses. So, simply attaining large thornless populations was a substantial limitation, and selection of superior progeny segregating for a range of quantitative traits made this a sizable challenge.

Crossing began in 1964 of semi-erect thornless $\times$ erect thorny. Crossing continued for many years, and slowly canes of progeny became more erect, and plant adaptation and fruit quality improved. In 1980, the selection Ark. 1172 was made, which had erect canes, good fruit quality, and good plant adaptation. It was released in 1989 as 'Navaho', the first thornless, erect blackberry cultivar (Moore and Clark, 1989). Thus, 25 years after Moore envisioned this product, the first cultivar was realized. By the late 1980 s to early 1990 s, the program had developed a large number of advanced erect, one-half thornless $\mathrm{F}_{1} \mathrm{~s}$ along with a substantial number of thornless, erect selections. The use of these as parents, particularly the thornless by thornless crosses, yielded large numbers of thornless progeny. These developments, coupled with muchincreased seed germination, allowed for the production of large populations of thornless progeny from which to select. Subsequent releases were 'Arapaho' (Moore and Clark, 1993), 'Apache' (Clark and Moore, 1999), and 'Ouachita'(Clark and Moore, 2005). 'Arapaho' is also early ripening, with maturity about 1 month earlier than 'Chester Thornless', which generally represents the average ripening date of the semi-erect parent material. This was achieved by repeated crossing of early ripening parents that contained thornless genes.

Diligence and perseverance were rewarded not only in the attainment of erect canes in the new thornless cultivars, but testing of these new developments in the deep southern U.S. revealed that they were also resistant to the devastating disease double blossom/rosette [caused by Cercosporella rubi (Wint.) Plakidas] to which most of the previous thorny cultivars were highly susceptible (Buckley et al., 1995). This resistance was not known at the time of the release of 'Navaho' as the disease did not occur where the breeding program was based, the University of Arkansas Fruit Substation, Clarksville.

\section{Breeding Primocane-fruiting Blackberries}

Before 2004, there were no commercial primocane-fruiting blackberry cultivars. Earlier, primocane-fruiting red raspberries arrived on the market and these have proven to be valuable to the expansion of red raspberry production. One might believe that the development of primocane-fruiting blackberries was not possible due to a lack of germplasm or the trait being intractable. However, neither of these reasons fully explains the delayed development of primocane-fruiting blackberries. This trait simply did not get much attention until the late 1980s to 1990s; one must keep in mind that blackberry is a very minor crop and few 
breeding programs have included blackberry in their program priorities.

The first recorded occurrence of a primocane-fruiting blackberry was of a wild plant found by L.G. Hillquist of Ashland, Va. Hillquist provided this genotype to the New York State Agricultural Experiment Station in 1949 (USDA, 2004). There is no evidence that this genotype was ever officially named, but likely was assigned the cultivar name 'Hillquist' as a designation in New York. This plant was noted to have a rudimentary level of primocane fruiting in Geneva. 'Hillquist' is a diploid (Thompson, 1995). There is no record of breeding with this plant until Moore attained it in the mid-1960s while accumulating germplasm for the University of Arkansas breeding program. Fortunately, 'Hillquist' is erect-caned, and this contributed to it being used in crossing in Arkansas. Moore made a cross of 'Brazos' by 'Hillquist' in 1967, and a selection was made from this population and designated as Ark. 593. It was assumed that 'Hillquist' produced an unreduced male gamete to combine with the female gamete of 'Brazos'. Based on its success as a parent, Ark. 593 was determined to be a tetraploid selection. Ark. 593 did not express the primocane-fruiting trait, but was used in subsequent crossing mainly due to its early ripening and thus primocane alleles were distributed among selections in the Arkansas program. In the late 1980s, James Ballington of North Carolina State Univ. obtained plants of Ark. 593, selfed this selection, and recovered primocane-fruiting offspring. Ballington and Moore (1995) released the germplasm selection NC 194. Ballington also hypothesized that the primocane trait was recessive based on his research. Subsequently this recessive inheritance was later confirmed (Lopez-Medina et al., 2000). From the seedlings produced in Lopez-Medina's inheritance study, fourteen primocane-fruiting selections were made in September 1997. Two of these were released in 2004 as 'Prime-Jan' (=APF-8) and 'Prime-Jim' (=APF-12)(Clark etal., 2004). Using the Lopez-Medina model, the crossing of two primocane-fruiting parents would yield only primocane-fruiting offspring. And, once a range of primocane-fruiting parents were produced, substantial offspring could be produced quickly to improve on this plant type. However, subsequent crossing in Arkansas, particularly the crossing of 'Prime-Jan' $\times$ 'Prime-Jim', has yielded nonprimocane-fruiting offspring. The reason for this is not fully understood, but there are likely other genes involved with primocane fruiting, though not envisioned to be as difficult to manage as one might consider for an intractable trait.

\section{Breeding for Flavor}

Little has been reported in the breeding for flavor of eastern U.S. blackberries. Blackberries from this region of the country have distinct flavor differences from those of the Pacific
Northwest cultivars, such as 'Marion', that contain $R$. ursinus germplasm. Is breeding for flavor an intractable trait? It is doubtful that one would classify flavor in this way. However, that may be a limited view of the situation as most breeding within eastern U.S. types has usually focused on increased soluble solids and/or reduced acidity with little emphasis on flavor components or volatiles. However, the movement of diverse flavors from 'Marion' or similar cultivars can be difficult. Reasons are that many of these genotypes with these diverse flavors are of a different ploidy level, along with undesirable associated traits including lack of winter hardiness and trailing cane habit. However, a concerted effort to increase flavor both within the eastern U.S. germplasm (focusing on increased soluble solids and possibly reduced acidity along with flavor volatile enhancement) and in hybrids with other blackberry germplasm will provide for progress in this effort.

\section{Other Possible Intractable Traits}

One might have surveyed the blackberry germplasm 50 years ago and determined that very large fruit size (actually measured by weight; for example in excess of $10 \mathrm{~g}$ ) would be difficult or impossible to attain. Fruit size has had great advances made. Large-fruited eastern U.S. cultivars include 'Kiowa' (which can average $13 \mathrm{~g}$ for a season with larger individual berries attained in some harvests) (Moore and Clark, 1996) and 'Chesapeake', up to $15 \mathrm{~g}$ primary berries (Clark and Finn, 2002). Berry weight up to $30 \mathrm{~g}$ has been attained in Arkansas in breeding selections. However, with the current interest in fresh market shipping of blackberries, fruit size $>8 \mathrm{~g}$ is often considered undesirable due to problems with the fitting of the large fruit in the clamshell container and adequate container fill to make the specified weight designation of the unit.

Another intractable trait that might have been considered difficult to achieve years ago is fruit firmness with shelf life adequate for shipping. Blackberries have long been considered one of the more difficult fruit to ship due to fruit softening and leakage. In eastern U.S. blackberries, the thornless cultivars have made great strides in this area. 'Chester Thornless' is likely the most widely shipped blackberry in the world, even though it was not selected or developed with this use as a primary focus (shipping use is observational information attained by J.R. Clark in viewing production or communicating with blackberry producers worldwide). 'Navaho' has exceptional shipping quality (Perkins-Veazie et al., 1997), and the other Arkansas thornless cultivars 'Arapaho', 'Apache', and 'Ouachita' have performed well in storage trials or in the shipping industry. More recently, fruit with a near crisp texture has been selected in the Arkansas program, and genotypes with this trait are in use as parents to further enhance fruit firmness and shipping capability.

\section{Conclusions}

Moore has told the story many times of attending a professional meeting in the early 1960s in which a contemporary small fruit breeder at the time commented that he felt that about everything had been done to improve eastern U.S. blackberries. Looking back on that comment now, $>40$ years later, this has been shown not to be true. Perseverance in the areas of enhanced fruit size and quality, erect canes, and more recently primocane fruiting have completely changed the cultivar profile for eastern U.S. blackberries. The horizon still holds many genetic improvement opportunities for this expanding crop.

\section{Literature Cited}

Ballington, J.R. and J.N. Moore. 1995. NC 194 primocane-fruiting, thorny, erect tetraploid blackberry germplasm. Fruit Var. J. 49:101-102.

Buckley, J.B., J.N. Moore, and J.R. Clark. 1995. Blackberry cultivars differ in susceptibility to rosette disease. Fruit Var. J. 49:235-238.

Clark, J.R. and C.E. Finn. 2002. Blackberry and hybrid berries. In: W.R. Okie (ed.). Register of new fruit and nut varieties List 44. HortScience $37: 251$.

Clark, J.R. and J.N. Moore. 1999. ‘Apache'thornless blackberry. HortScience 34:1291-1293.

Clark, J.R. and J.N. Moore. 2005. 'Ouachita' thornless blackberry. HortScience 40:258-260.

Clark, J.R., J.N. Moore, J. Lopez-Medina, P. PerkinsVeazie, and C.E. Finn. 2005. 'Prime Jan'(APF-8) and 'Prime Jim' (APF-12) primocane-fruiting blackberries. HortScience 40:852-855

Daubeny, H. 1997. Blackberry and hybrid berries. In: W.R. Okie (ed.). Register of new fruit and nut varieties Brooks and Olmo List 38. HortScience 32:785-786.

Finn, C.E. and J.R. Clark. 2000. Blackberry and hybrid berries. In: W.R. Okie (ed.). Register of new fruit and nut varieties List 40. HortScience 35:814.

Jennings, D.L. 1988. Raspberries and blackberries: Their breeding, diseases and growth. Academic Press, London.

Lopez-Medina, J., J.N. Moore, and R.W. McNew. 2000. A proposed model for inheritance of primocane fruiting in tetraploid erect blackberry. J. Amer. Soc. Hort. Sci. 125:217-221.

Moore, J.N. 1997. Blackberry, p. 161-173. In: The Brooks and Olmo register of fruit and nut varieties. 3rd ed. ASHS Press, Alexandria, Va.

Moore, J.N. and J.R. Clark. 1989. 'Navaho' thornless blackberry. HortScience 24:863-865.

Moore, J.N. and J.R. Clark. 1993. 'Arapaho' erect thornless blackberry. HortScience 28:861-862.

Moore, J.N. and J.R. Clark. 1996. 'Kiowa'blackberry. HortScience 31:286-288.

Perkins-Veazie, P., J.K. Collins, J.R. Clark, and L. Risse. 1997. Air shipment of 'Navaho' blackberry fruit to Europe is feasible. HortScience 32:132.

Thompson, M.M. 1995. Chromosome numbers of Rubus cultivars at the National Clonal Germplasm Repository. HortScience 30:1453-1456.

U.S. Dept. of Agriculture, Agricultural Research Service, National Genetic Resources Program. 2004. Germplasm Resources Information Network (GRIN). 9 Nov. 2004. http://www.ars-grin.gov/ cgi-bin/npgs/html/acc_search.pl?accid=Hillquist. Natl. Germplasm Resour. Lab., Beltsville, Md. 